\title{
COMPARISON OF INSERTION RATE OF L1 RETROPOSON INTO INTRON 30 OF THE NEUROFIBROMATOSIS TYPE 1 GENE IN SEVEN ASIAN AND PACIFIC POPULATIONS
}

\author{
Taku ShIRAKAwA, ${ }^{1}$ Kaoru NishiYama, ${ }^{1}$ Lai PoH-SAN, ${ }^{2}$ \\ Takafumi IsHIDA, ${ }^{3}$ and Masafumi MATSUO ${ }^{4, *}$ \\ ${ }^{1}$ Faculty of Health Science, Kobe University School of Medicine, \\ 7-10-2 Tomogaoka, Suma-ku, Kobe 654-01, Japan \\ ${ }^{2}$ Department of Pediatrics, National University of Singapore, \\ Singapore 0511, Singapore \\ ${ }^{3}$ Department of Anthropology, Faculty of Science, \\ The University of Tokyo, Tokyo 113, Japan \\ ${ }^{4}$ Division of Genetics, International Center for Medical Research, \\ Kobe University School of Medicine, 7-5-1 Kusunoki-cho, \\ Chuo-ku, Kobe 650, Japan
}

\begin{abstract}
Summary The allele frequency of a $\mathrm{L} 1$ retroposon insertion into intron 30 of the neurofibromatosis type 1 (NF1) gene was determined by analyzing amplified fragment lengths in seven Asian or Pacific populations; namely, Japanese, Chinese, Indian, Malay, Filipino, Indonesian and New Guinean. Nearly 100 chromosomes from each group were analyzed. The presence of the L1 insertion was identified by the appearance of an abnormally large PCR-amplified product. The insertion frequency varied from 0.45 to 0.75 , depending on the population group. Malay and Indonesian populations were found to have the highest insertion frequencies ( 0.75 and 0.72 , respectively), while the wild-type genotype was more prevalent in Indians. The lowest insertion frequency (0.45), observed in Indians, was nearest to that reported in Westerners (0.35). The different L1 insertion frequencies found in Asian and Pacific groups reflect a major divergence in these human populations. Japanese and Chinese populations showed the highest heterozygosity $(0.50)$, suggesting the usefulness of this polymorphism in linkage analysis in these populations.
\end{abstract}

Received September 11, 1995; Revised version accepted December 1, 1995.

* To whom correspondence should be addressed. 
Key Words NF1, neurofibromatosis, polymorphism, L1, retrotransposon

\section{Introduction}

Neurofibromatosis type 1 (NF1) is an autosomal, dominant disorder affecting 1 in 3,000 individuals, with about 50\% of those affected carrying new mutations. NF1 is characterized by peripheral neurofibromas, cafe-au-lait spots and Lisch nodules in the iris. The NF1 gene is contained within a genomic fragment of 300 $\mathrm{kb}$ with an open reading frame coding for 2,818 amino acids. Individuals with NF1 have an increased risk of developing benign and malignant tumors. The NF1 gene has been reported to be completely inactivated in some malignant NF1 tumors (Legius et al., 1993) and in some non-NF1 related tumors (Andersen et al., 1993; The et al., 1993). However, the large size of the gene and the large number of exons it contains have made the identification of causative mutations difficult. Until now, only 152 mutations have been reported in the literature (Upadhyaya et al., 1994). Therefore, most genetic studies on NFl patient depend on linkage analysis (Jorde et al., 1993; Lazaro et al., 1993; Upadhyaya et al., 1994).

L1 elements are a family of long, interspersed, repetitive DNA sequences that are present at $\sim 10^{5}$ copies (full-length and truncated) dispersed throughout the genome. The human full-length $\mathrm{L} 1$ element comprises $6.1 \mathrm{~kb}$, and contains two long open reading frames (ORFs), the second of which could encode a polypeptide having sequence similarity to reverse transcriptase. These structural characters suggest that L1 elements are capable of transposition via of an RNA intermediate (Hutchinson et al., 1989). Most of the L 1 elements identified in the human genome have retrotransposed at some time in the past and are truncated at their $5^{\prime}$ end.

Recently, a 351 bp long segment of intron 30 of the NF1 gene was identified as a $5^{\prime}$ truncated L1 retroposon (Bleyl et al., 1994). This L1 sequence includes 124 bp of the fragment corresponding to the previously defined $3^{\prime}$ ORF in reverse orientation to the NF1 gene. The absence or presence of this L1 insertion is responsible for the TaqI polymorphism which had been identified by using Southern hybridization. As this insertion can be readily identified by the increased size of the product amplified by polymerase chain reaction (PCR), analysis of this polymorphism could provide a useful marker for use in linkage analysis in highly heterozygous populations. L1 insertion is found relatively infrequently in the NF1 gene in Caucasians but its frequency in other populations has not been determined. We report here an investigation of the frequency of this insertion among seven Asian and Pacific populations.

\section{Materials and Methods}

DNA samples. Whole blood samples were obtained from unrelated individuals from each population group. Samples were taken at the Kobe University Hospital, Kobe, Japan, at the National Singapore University Hospital, Singapore, 
at the Dr. Sardjitio Hospital Gadjah Mada University, Yogyakarta, Indonesia, and at the Philippine General Hospital, Manila, the Philippines, from neonates who were subjected for screening of other diseases. Blood samples were also collected from volunteers in Papua New Guinea. In Singapore, DNA samples from individuals from three ethnic groups (Chinese, Indian and Malay) were obtained after making sure that at least the last three generations in the families of each individual were from the same ethnic group. DNA was extracted by the phenol/chloroform method from thawed frozen blood samples.

DNA amplification. PCR amplification of the L1 insertion site in intron 30 of the NF1 gene was carried out using the primers 5'-CCTTAATCATGAAGGGTGCTGACC-3' and $5^{\prime}$-GCATGTGCCATGGTGCCTGGCT- $3^{\prime}$. The PCR was carried out in a volume of $20 \mu \mathrm{l}$ containing each primer, each dNTP, and Taq Polymerase (Takara, Kyoto, Japan). After initial denaturation at $94^{\circ} \mathrm{C}$ for $5 \mathrm{~min}$, reactions were subjected to 33 cycles of denaturation at $94^{\circ} \mathrm{C}$ for $60 \mathrm{sec}$, annealing at $65^{\circ} \mathrm{C}$ for $60 \mathrm{sec}$ and extension at $72^{\circ} \mathrm{C}$ for $120 \mathrm{sec}$. PCR products were resolved by electrophoresis in $3 \%$ agarose gel.

Sequencing of PCR products. The amplified DNA was treated with T4 DNA polymerase (Life Technologies, Inc., Grand Island, NT) and subcloned into SmaI-digested pGEN 7Zf $(+)$ (Promega Co., Madison, WI). The sequences of inserted DNA from three or four clones were determined by an automatic DNA sequencer (model 373A: Applied Biosystems Inc., Foster City, CA) using the Taq dyeprimer cycle sequencing kit (Applied Biosystems Inc., Foster City, CA).

\section{Results}

A region encompassing the $\mathrm{L} 1$ insertion site of intron 30 of the NF1 gene was amplified from each DNA by using a set of primers described in Materials and Methods. Two different sizes of DNA could be amplified and three amplification patterns were observed; one having a single product of around $150 \mathrm{bp}$, one having a single product of around $500 \mathrm{bp}$, and one having both small and large products. Only the larger product was close to the expected size calculated from the original sequence data (Weiss et al., 1992). When the two amplified products were sequenced, the larger product ( $505 \mathrm{bp}$; allele 505) was found to match the original sequence perfectly (Weiss et al., 1992). However, the smaller product lacked nucleotides 43909 to 44261 (numbering according to Weiss et al. (1992)), although the rest of the nucleotide sequence was exactly the same as that of the clone originally sequenced. The size of the amplified product was $154 \mathrm{bp}$ (allele 154). The additional 351 nucleotides present in allele 505 were identified as a $5^{\prime}$ truncated L1 insertion, as reported by Bleyl et al. (1994). The identical L1-derived insertion was identified in the larger PCR product in every population studies (data not shown).

Among 50 DNA samples from Japanese individuals, 7 and 18 were homozygous for the 154 or 505 alleles, respectively. The remaining 25 (50\%) were 
Table 1. Amplification results of intron 30 of the NF1 gene.

\begin{tabular}{lccccccc}
\hline Genotype & Japanese & Chinese & Indian & Filipino & Malay & $\begin{array}{c}\text { Papua New } \\
\text { Guinean* Indonesian }\end{array}$ \\
\hline $154 / 154$ & $7(14)$ & $5(10)$ & $16(32)$ & $11(22)$ & $3(6)$ & $7(18)$ & $7(14)$ \\
$505 / 505$ & $18(36)$ & $20(40)$ & $11(22)$ & $19(38)$ & $28(56)$ & $19(50)$ & $29(58)$ \\
$154 / 505$ & $25(50)$ & $25(50)$ & $23(46)$ & $20(40)$ & $19(38)$ & $12(32)$ & $14(28)$ \\
\hline Insertion frequency & 0.61 & 0.65 & 0.45 & 0.58 & 0.75 & 0.66 & 0.72 \\
\hline
\end{tabular}

Genotypes were named according to their allele. Numbers of cases analyzed are described and their percentage in each group are shown in parenthesis. ${ }^{*} 76$ chromosomes were analyzed.

heterozygous (Table 1). To survey the distribution of L1 insertions, NF1 genes from 100 chromosomes in each of the Chinese, Indian, Malay, Filipino and Indonesian (central Java) populations, and from 76 chromosomes from Papua New Guinea were analyzed (Table 1). The highest insertion frequencies were observed in Malay (0.75) and Indonesian (0.72) individuals (Table 1). High insertion frequencies were also observed in Chinese (0.65) and Japanese (0.61), while the L1 insertion frequency was lowest in Indians (0.45). Table 1 also shows that Japanese and Chinese individuals demonstrated the highest heterozygosity for this insertion (50\%), whereas Indians, Filipinos and Malays showed heterozygosities of 46,40 and $38 \%$ respectively.

\section{Discussion}

Retroposon L1 can transpose to new sites in the human genome, where its copy number is still increasing. Sometimes, evidence of retrotransposition is obtained when transposition results in the development of disease. At least five recent reports implicate $\mathrm{L} 1$ element insertions as the cause of diseases: three in the factor VIII gene (Kazazian et al., 1988; Woods-Samuels et al, 1989), one in the APC tumor suppresser gene (Miki et al., 1992), and one in the dystrophin gene (Narita et al., 1993). An example of de novo insertion of a retrotransposon in the NF1 gene has been reported: the Alu sequence, another family of retroposon, was identified upstream of an A-T stretch in intron 5 of the NF1 gene, resulting in a splicing error (Wallace et al., 1991). This report suggests that the NF1 gene itself could be a target for retroposon insertion, which is favored by certain genome nucleotide sequences (Fanning and Singer, 1987). Recently Bleyl et al. demonstrated the presence of a silent $L 1$ sequence in intron 30 of the NF1 gene. This insertion was estimated to have occurred before the divergence of humans into present-day racial groupings (Bleyl et al, 1994). Partial deletion of a silent Alu sequence has been identified in intron 27 of the NF 1 gene (Lazaro et al., 1993). Our sequencing results showed all $\mathrm{L} 1$ sequences in intron 30 of NF1 are completely identical in the seven populations studied. This finding agrees with the theory that this insertion occurred before these populations diverged.

This paper is the first report describing the $\mathrm{L} 1$ insertion frequencies in the 
NF1 gene in Asian and Pacific populations. The results showed different frequencies of retroposon insertion in the different populations. It has been previously reported that this polymorphism is present with an insertion frequency of 0.35 in Caucasians (Bleyl et al., 1994); our results show that the insertion frequency is higher in some of the mongoloid populations, and especially high in some groups such as Malays (0.75) and Indonesians (0.72) (Table 1). These two populations are believed to have a common ancestor in South China (Bowcock et al., 1994). Further, it was shown that $\mathrm{L} 1$ insertion frequencies are similar in the Japanese and Chinese populations, indicating a closer genealogy (Table 1). Likewise, the frequency of $\mathrm{Ll}$ insertion in intron 30 of the NF1 gene in Indians is similar to that in Caucasians. These variations correlate well with the expected divergence of these racial groups (Bowcock et al., 1994).

Heterozygosity of this insertion in Caucasians was reported to be $41 \%$ (Bleyl et al., 1994). In comparison, the rates were higher in Japanese and Chinese populations (50\%) (Table 1). This result indicates the usefulness of L1 insertion polymorphism as an intragenic marker for linkage analysis of the NF1 gene in these populations. We suggest that analysis of this polymorphism will facilitate the identification of cases with deletion of the entire NFI gene (Kayes et al., 1994), which shows up as the disappearance of one allele in linkage analysis. This polymorphism marker can thus be used together with other previously-reported markers, which showed heterozygosity rates ranging from $41 \%$ to $82 \%$ in linkage analysis of NF1 (Rodenhiser et al., 1993; Upadhyaya et al., 1994).

Acknowledgments We thank Dr. A. Pugsley for advice and for critically reading the manuscript, and Miss A. Maruyama for her help in preparing the manuscript. This work was supported by grants from the Ministry of Education, Science and Culture of Japan.

\section{REFERENCES}

Andersen L, Fountain J, Gutmann D, Tarle S, Glover T, Dracopoli N, Housman D, Collins F (1993): Mutations in the neurofibromatosis 1 gene in sporadic malignant melanoma cell lines. Nature Genet 3: 118-121

Bleyl S, Ainsworth P, Nelson L, Viskochil D, Ward K (1994): An ancient Ta subclass L1 insertion results in an intragenic polymorphism in an intron of the NF1 gene. Hum Mol Genet 3: $517-518$

Bowcock AM, Ruiz-Linares A, Tomfohrde J, Minch E, Kidd JR, Cavalli-Sforza LL (1994): High resolution of human evolutionary trees with polymorphic microsatellites. Nature 368: 455457

Fanning TG, Singer MF (1987): LINE-1: a mammalian transposable element. Biochem Biophys Acta 910: 203-212

Hutchinson CA, Hardies SC, Loeb DD, Shehee WR, Edgell MH (1989): LINEs and related retroposons: Long interspersed repeated sequences in the eukaryotic genome. In: Berg D, Howe M (eds). Mobile DNA. American Society for Microbiology, Washington, DC, pp 593617

Jorde LB, Wakins WS, Viskochil D, O'Connell P, Ward K (1993): Linkage disequilibrium in the neurofibromatosis $\mathrm{I}(\mathrm{NF} 1)$ region: Implications for gene mapping. Am J Hum Genet 53: $1038-1050$

Vol. 41, No. 1, 1996 
Kayes LM, Burke W, Riccardi VM, Bennett R, Ehrlich P, Rubenstein A, Stephens K (1994): Deletions spanning the neurofibromatosis $I$ gene: identification and phenotype of five patients. Am J Hum Genet 54: 424-436

Kazazian HH, Wong C, Youssoufian H, Scott AF, Phillips DH, Antonarakis E (1988): Haemophilia A resulting from de novo insertion of $\mathrm{L} 1$ sequences represents a novel mechanism for mutation in man. Nature 332: 164-166

Lazaro C, Gaona A, Ravella A, Volpini V, Casals T, Fuentes J-J, Estivill X (1993): Novel alleles, hemizygosity and deletions at an Alu-repeat within the neurofibromatosis type 1 (NF1) gene. Hum Mol Genet 2: 725-730

Legius E, Marchuk D, Collins F, Glover T (1993): Somatic deletion of the neurofibromatosis type 1 gene in a neurofibrosarcoma supports a tumour suppressor gene hypothesis. Nature Genet 3: $122-126$

Miki Y, Nishio I, Horii A, Miyoshi Y, Utsunomiya J, Kinzler K, Vogelstein K, Nakamura Y (1992): Disruption of the APC gene by a retrotransposal insertion of L1 sequence in a colon cancer. Canser Res 52: 643-645

Narita N, Nishio H, Kitoh Y, Ishikawa Y, Ishikawa Y, Minami R, Nakamura H, Matsuo M (1993): Insertion of a $5^{\prime}$ truncated L1 element into the $3^{\prime}$ end of exon 44 of the dystrophin gene resulted in skipping of the exon during splicing in a case of Duchenne muscular dystrophy. J Clin Invest 91: 1862-1867

Rodenhiser D, Coulter-Mackie M, Singh S (1993): Evidence of DNA methylation in the neurofibromatosis type 1 (NF1) gene region of 17q11.2. Hum Mol Genet 2: 439-444

The I, Murthy AE, Hannigan GE, Jacoby LB, Menon AG, Gusella JF, Bernards A (1993): Neurofibromatosis type 1 gene mutations in neuroblastoma. Nature Genet 3: 62-66

Upadhyaya M, Shaw DJ, Harper PS (1994): Molecular basis of neurofibromatosis type 1 (NF1): Mutation analysis and polymorphisms in the NF1 gene. Hum Mutation 4: 83-101

Wallace MR, Andersen LB, Saulino AM, Gregory PE, Glover TW, Collins FS (1991): A de novo Alu insertion results in neurofibromatosis type 1. Nature 353: 864-866

Weiss RB, Dunn D, DiSera L, Wheatley W, Kimball A, Rote C, Cherry J, Duval B, Lee R, Ferguson MW, Gestland RF (1992): The human neurofibromatosis type 1 locus; genomic sequence of the $3^{\prime}$ region. GenBank accession no. L03723

Woods-Samuels P, Wong C, Mathias SL, Scott AF, Kazazian HH, Antonarrakis SE (1989): Characterization of a nondeleterious $\mathrm{Ll}$ insertion in an intron of the human factor VIII gene and further evidence of open reading frames in functional LI elements. Genomics 4: 290-296 